
RESEARCH AND DEVELOPMENT

\author{
http://journal.unnes.ac.id/sju/index.php/higeia
}

\title{
KEJADIAN DEMAM TIFOID DI WILAYAH KERJA PUSKESMAS PAGIYANTEN
}

\section{Farissa Ulfa ${ }^{\bowtie}$, Oktia Woro Kasmini Handayani}

Epidemiologi dan Biostatistik, Jurusan Ilmu Kesehatan Masyarakat, Fakultas Ilmu Keolahragaan, Universitas Negeri Semarang

\begin{tabular}{l}
\hline Info Artikel \\
\hline Sejarah Artikel: \\
Diterima Februari 2018 \\
Disetujui Maret 2018 \\
Dipublikasikan April \\
2018 \\
\hline Keywords: \\
Risk Factors, Typhoid \\
Fever, Habit
\end{tabular}

\begin{abstract}
Abstrak
Kasus demam tifoid di Kabupaten Tegal pada tahun 2016 yaitu sebanyak 11.387 kasus dan Puskesmas Pagiyanten merupakan salah satu puskesmas dengan jumlah kasus demam tifoid tertinggi yaitu sebanyak 377 kasus. Penelitian ini dilakukan pada tahun 2017 dan bertujuan untuk mengetahui faktor-faktor yang berhubungan dengan kejadian demam tifoid di Puskesmas Pagiyanten Kabupaten Tegal. Jenis penelitian yang digunakan adalah studi case control dengan sampel sebesar 43 kasus dan 43 kontrol. Instrumen yang digunakan adalah lembar kuesioner. Analisis data dilakukan secara univariat dan bivariat dengan menggunakan uji chi-square. Hasil yang didapatkan faktor yang berhubungan dengan kejadian demam tifoid meliputi kebiasaan makan di luar rumah ( $p$-value $=0,001)$, kebiasaan mencuci tangan sebelum makan ( $p$-value $=0,02$ ), kebiasaan mencuci tangan setelah BAB ( $p$-value $=0,04)$, kebiasaan mencuci bahan makanan mentah ( $p$-value $=0,007)$, dan jamban sehat $(p$-value $=0,04)$. Simpulan penelitian ini adalah terdapat hubungan antara kebiasaan makan di luar rumah, kebiasaan mencuci tangan sebelum makan, kebiasaan mencuci tangan setelah BAB, kebiasaan mencuci bahan makanan mentah, dan jamban sehat dengan kejadian demam tifoid di Puskesmas Pagiyanten Kabupaten Tegal.
\end{abstract}

\begin{abstract}
Typhoid fever in Tegal regency in 2016 were 11,387 cases, and Puskesmas Pagiyanten with the highest number of cases of typhoid fever of 377 cases. The study was conducted in 2017 and it was purposed to determine the factors associated with the incidence of typhoid fever in Puskesmas Pagiyanten Tegal regency. The research used case control study with 43 cases and 43 controls. The instrument used a questionnaire. The data were analyzed by univariate and bivariate using chi-square test. The results of factors related to the occurrence of typhoid fever include eating habits outside the home (p-value $=0.001)$, hand washing before eating habits ( $p$-value $=0.02$ ), hand washing habit after defecate ( $p$-value $=0.04)$, the habit of washing raw food ( $p$ value $=0,007$ ), and healthy latrines ( $p$-value $=0,04$ ). The conclusion of this research there was a relationship between eating habits outside the home, the habit of washing hands before eating, habit of washing hands after defecate, the habit of washing raw food, and healthy latrines with the incidence of typhoid fever in Puskesmas Pagiyanten Kabupaten Tegal.
\end{abstract}

(C) 2018 Universitas Negeri Semarang

Alamat korespondensi:

Gedung F5 Lantai 2 FIK Unnes

p ISSN 1475-362846

Kampus Sekaran, Gunungpati, Semarang, 50229

e ISSN 1475-222656

E-mail: farissa1224@gmail.com 


\section{PENDAHULUAN}

Demam tifoid adalah penyakit infeksi bakteri yang menyerang sistem pencernaan manusia yang disebabkan oleh Salmonella typhi dengan gejala demam satu minggu atau lebih disertai gangguan pada saluran pencernaan dan dengan atau tanpa gangguan kesadaran (Rampengan, 2007). Demam tifoid di negara maju terjadi mencapai 5.700 kasus setiap tahunnya, sedangkan di negara berkembang demam tifoid mempengaruhi sekitar 21,5 juta orang per tahun (CDC, 2013 dalam Batubuaya, 2017). Secara global diperkirakan setiap tahunnya terjadi sekitar 21 juta kasus dan 222.000 menyebabkan kematian. Demam tifoid menjadi penyebab utama terjadinya mortalitas dan morbiditas di negara-negara berpenghasilan rendah dan menengah (WHO, 2016 dalam Batubuaya, 2017). Penelitian Sur (2007) yang dilakukan di Kolkata, India menyatakan bahwa daerah dengan risiko tinggi terkena demam tifoid adalah daerah dengan status ekonomi rendah.

Prevalensi demam tifoid di Indonesia sebesar $1,60 \%$, tertinggi terjadi pada kelompok usia 5-14 tahun, karena pada usia tersebut anak kurang memperhatikan kebersihan diri serta kebiasaan jajan sembarangan yang dapat menyebabkan penularan penyakit demam tifoid. Prevalensi menurut tempat tinggal paling banyak di pedesaan dibandingkan perkotaaan, dengan pendidikan rendah dan dengan jumlah pengeluaran rumah tangga rendah (Depkes RI, 2008).

Prevalensi demam tifoid di Jawa Tengah sebesar 1,6\%, dan tersebar di seluruh Kabupaten/Kota dengan rentang 0,2 - 3,5\% (Depkes RI, 2008). Menurut data SKDR (Sistem Kewaspadaan Dini dan Respon), sepanjang tahun 2016 di Jawa Tengah tercatat sebagai provinsi dengan kasus penyakit suspek demam tifoid tertinggi yaitu sebanyak 244.071 kasus yang tersebar di seluruh Kabupaten/Kota. Dari data tersebut diperoleh Kabupaten Tegal menduduki peringkat ke-5 dengan suspek demam tifoid tertinggi yaitu sebanyak 11.387 kasus yang tersebar di seluruh kecamatan, mengalami kenaikan kasus dari tahun 2015 yaitu 165 kasus. Berdasarkan Profil Kesehatan Kabupaten Tegal tahun 2015, jumlah penduduk dengan akses sanitasi layak (jamban sehat) sebanyak 861.700 orang $(62,1 \%)$, sedangkan cakupan rumah sehat sebanyak 103.122 orang $(31,6 \%)$ dan masih dibawah target nasional yaitu sebesar $85 \%$.

Puskesmas Pagiyanten merupakan salah satu dari 10 puskesmas rawat inap yang ada di Kabupaten Tegal. Pada tahun 2014 jumlah pasien yang menderita demam tifoid dan dirawat inap di puskesmas tersebut sebanyak 316 pasien. Pada tahun 2015 jumlah pasien rawat inap yang menderita demam tifoid mengalami peningkatan menjadi 370 pasien dan kembali meningkat di tahun 2016 yaitu sebanyak 377 pasien. Puskesmas tersebut merupakan peringkat ke-5 puskesmas rawat inap dengan jumlah kasus suspek demam tifoid tertinggi se-Kabupaten Tegal.

Berdasarkan studi pendahuluan yang dilakukan di Puskesmas Pagiyanten, sebanyak 12 pasien yang menderita demam tifoid berada pada kelompok umur 5-13 tahun yang terdiri dari 7 orang berjenis kelamin perempuan dan 5 orang laki-laki. Selain itu didapatkan pula sebesar $16,6 \%$ dari pasien mempunyai anggota keluarga yang sebelumnya pernah menderita demam tifoid yang tinggal serumah, sebesar $100 \%$ pasien mencuci alat makan dan minum dengan sabun dan air mengalir, dan 58,3\% pasien menyimpan makanan atau hidangan dalam keadaan tertutup. Dilihat dari kebiasaan pasien, sebesar $50 \%$ dari pasien mempunyai kebiasaan mencuci tangan yang belum sesuai dengan langkah cuci tangan yang baik dan benar. Dari 12 pasien yang diwawancara didapatkan sebesar $83,3 \%$ mempunyai kebiasaan makan diluar rumah seperti warung, rumah makan, jajanan sekolah, ataupun pedagang keliling serta 33,3\% dari pasien tidak mencuci bahan makanan mentah yang akan langsung dimakan. Hasil observasi mengenai sanitasi lingkungan meunjukkan bahwa sarana pembuangan tinja yang memenuhi syarat jamban sehat diperoleh sebesar $66,7 \%$ rumah responden yang memenuhi syarat. 
Penularan penyakit ini adalah melalui air dan makanan yang terinfeksi Salmonella typhi. Kuman Salmonella dapat bertahan lama dalam makanan. Dengan adanya penularan tersebut dapat dipastikan higyene makanan dan higyene personal sangat berperan dalam masuknya bakteri ke dalam makanan (Kusuma, 2015). Demam tifoid dapat berakibat fatal jika tidak dirawat. Penyakit ini dapat berlangsung selama tiga minggu sampai sebulan. Penyebab paling umum kematian akibat demam tifoid adalah perforasi usus atau perdarahan usus, yang selanjutnya menimbulkan peritonitis. Komplikasi ini diramalkan terjadi pada $5 \%$ pasien, rata-rata pada hari ke-21 sejak awal penyakit, dengan angka kematian kasus $45 \%$. Demam tifoid yang berupa syok septik atau komplikasinya berupa koma, juga mempunyai angka kematian tinggi, pasien sering meninggal dalam 3 minggu pertama (Tjipto, 2009). Berdasarkan penelitian yang dilakukan Parry (2014) menyatakan bahwa dari 581 orang di Vietnam yang menderita demam tifoid terdapat 90 orang $(15,5 \%)$ mengalami komplikasi diantaranya perdarahan gastrointestinal (43; 7,4\%); Hepatitis (29; 5,0\%); Ensefalopati (16; 2,8\%); Miokarditis (12; 2,1\%); Perforasi usus (6; 1,0\%); Syok hemodinamik (5; $0,9 \%)$, dan kematian $(3 ; 0,5 \%)$.

Terjadinya peningkatan jumlah kasus demam tifoid disebabkan karena demam tifoid merupakan penyakit yang multifaktorial artinya banyak faktor yang dapat memicu terjadinya demam tifoid antara lain umur, jenis kelamin, pendidikan, pekerjaan, sanitasi lingkungan, personal hygiene, serta tempat tinggal si penderita yang dapat mempengaruhi timbulnya penyakit tersebut (Ruztam, 2012). Penelitian yang dilakukan Maghfiroh (2016) dan Batubuaya (2017) menyebutkan bahwa faktor yang berhubungan dengan kejadian demam tifoid antara lain praktik cuci tangan sebelum makan, praktik cuci tangan setelah buang air besar, kondisi tempat pembuangan sampah, pengolahan makanan, kebiasaan makan di luar rumah, pekerjaan responden, dan tingkat pendapatan kepala keluarga. Sedangkan penelitian yang dilakukan oleh Nadyah (2014) menyebutkan bahwa faktor risiko paling dominan terjadinya demam tifoid adalah faktor lingkungan dan faktor sumber pengolahan makanan. Selain itu penelitian Malau (2015), Ramaningrum (2016) dan Nuruzzaman (2016) menyebutkan faktor risiko terjadinya demam tifoid pada anak antara lain umur responden, kebiasaan mencuci tangan sebelum makan dan setelah buang air besar yang kurang baik, kondisi kuku jari tangan yang kotor, sering jajan saat dirumah, membeli jajan di pedagang kaki lima, dan kemasan jajan yang terbuka. Penelitian Pramitasari (2013) juga menyebutkan beberapa faktor risiko yang berhubugan dengan kejadian demam tifoid antara lain adalah jenis kelamin laki-laki lebih berisiko daripada perempuan dengan hasil OR sebanyak 3,84, selain itu sumber air bersih yang digunakan berasal dari air sumur berisiko sebesar $\mathrm{OR}=2,25$.

Tujuan dari penelitian ini adalah untuk mengetahui faktor-faktor yang berhubungan dengan kejadian demam tifoid di Puskesmas Pagiyanten Kabupaten Tegal.

\section{METODE}

Jenis penelitian yang digunakan dalam penelitian ini adalah analitik observasional dengan desain penelitian case-control. Variabel bebas dalam penelitian ini adalah adalah umur responden, jenis kelamin, keadaan sosial ekonomi, kebiasaan makan di luar rumah, kebiasaan mencuci tangan sebelum makan, kebiasaan mencuci tangan setelah buang air besar, kebiasaan mencuci bahan makanan mentah yang akan dimakan langsung, riwayat keluarga yang menderita tifoid, dan sarana pembuangan tinja (jamban sehat). Variabel terikat dalam penelitian ini adalah kejadian demam tifoid. Variabel perancu dalam penelitian ini adalah riwayat demam tifoid pasien yang dikendalikan dengan cara retriksi. Responden yang dipilih untuk sampel penelitian adalah responden yang tidak memiliki riwayat demam tifoid sebelumnya (kasus baru).

Penelitian ini dilakukan di wilayah kerja Puskesmas Pagiyanten Kabupaten Tegal dari tanggal 3 Juli sampai dengan 4 Agustus 2017. 
Populasi kasus dalam penelitian ini adalah semua pasien yang dirawat inap dan menderita demam tifoid yang tercatat dalam rekam medik Puskesmas Pagiyanten Kabupaten Tegal pada tahun 2016 - 2017, sedangkan Populasi kontrol yaitu semua pasien yang tidak menderita demam tifoid dan pernah berobat di Puskesmas Pagiyanten Kabupaten Tegal selama tahun 2016 - 2017. Penentuan besar sampel minimal untuk kelompok kasus dan kelompok kontrol didapatkan berdasarkan pada penelitian terdahulu (penelitian yang dilakukan oleh Artanti, 2013), yaitu $\mathrm{OR}=3,6 ; \mathrm{P}_{1}=0,62 ; \mathrm{P}_{2}=0,31$ dengan tingkat kepercayaan $\left(Z_{\alpha}=95 \%\right)$ yaitu 1,96 .

Berdasarkan perhitungan rumus besar sampel didapatkan jumlah sampel minimal yaitu 43 orang. Penelitian ini menggunakan perbandingan kasus dan kontrol 1:1, sehingga didapatkan sampel penelitian ini sebanyak 86 responden yang terdiri dari 43 responden kasus dan 43 responden kontrol. Teknik pengambilan sampel pada penelitian ini dilakukan dengan menggunakan Purposive Sampling, yaitu dengan memilih beberapa sampel tertentu yang dinilai sesuai dengan tujuan dan masalah dalam penelitian. Kriteria inklusi pada kelompok kasus penelitian ini yaitu didiagnosis demam tifoid berdasarkan data Puskesmas Pagiyanten, bertempat tinggal di wilayah kerja Puskesmas Pagiyanten, dan pernah dirawat inap di Puskesmas Pagiyanten selama bulan Januari 2016 -Mei 2017, serta kriteria eksklusi pada kelompok kasus penelitian ini yaitu mempunyai riwayat penyakit demam tifoid dan alamat yang tidak jelas atau pindah tempat tinggal saat dilakukan penelitian. Sedangkan kriteria inklusi kontrol pada penelitian ini yaitu tidak mengalami tanda dan gejala penyakit demam tifoid, bertempat tinggal di wilayah kerja Puskesmas Pagiyanten, berobat di Puskesmas Pagiyanten selama bulan Januari 2016 - Mei 2017, serta kriteria eksklusi penelitian ini yaitu responden yang mempunyai riwayat penyakit demam tifoid.

Sumber data yang digunakan dalam penelitian ini adalah data primer dan sekunder. Data primer diperoleh melalui wawancara mendalam dengan responden, observasi, dan dokumentasi. Sedangkan data sekunder diperoleh dari Dinas Kesehatan Kabupaten Tegal dan Puskesmas Pagiyanten yang berisi data responden yang menderita demam tifoid. Instrumen yang digunakan untuk mengumpulkan data dalam penelitian ini adalah kuesioner yang berisi beberapa pertanyaan yang harus dijawab oleh responden dan lembar dokumentasi. Kuesioner yang digunakan dalam penelitian ini bertujuan untuk mengetahui informasi mengenai kondisi responden serta faktor-faktor yang berhubungan dengan kejadian demam tifoid. Kuesioner yang digunakan sebelumnya dilakukan uji validitas untuk mengetahui apakah alat ukur tersebut benar-benar mengukur apa yang diukur. Selain uji validitas juga dilakukan uji reliabilitas pada kuesioner yang menunjukkan bahwa apakah instrument cukup dapat dipercaya untuk dapat digunakan sebagai alat pengumpul data. Metode pengujian menggunakan rumus alpha memakai program SPSS versi 16.0.

Data yang sudah terkumpul kemudian akan dilakukan pemeriksaan / validasi data, pemberian kode dan penyusunan data yang kemudian akan dilakukan analisis statistik yang sesuai. Adapaun analisis statistik yang akan dilakukan dalam penelitian ini adalah analisis univariat dan bivariat. Analisis univariat digunakan untuk mendeskripsikan distribusi frekuensi pada variabel bebas yang disajikan dalam bentuk tabel dan narasi. Sedangkan analisis bivariat dilakukan terhadap variabel bebas dan variable terikat yang diduga berhubungan atau berkorelasi.

Analisis bivariat dalam penelitian ini menggunakan Chi Square dengan uji alternatif Fisher's exact test, untuk mengetahui ada tidaknya hubungan antara dua variabel yaitu variabel bebas dan variabel terikat. Perhitungan Confidens Internal (CI) digunakan taraf kepercayaan 95\% $(\alpha<0,05)$.

\section{HASIL DAN PEMBAHASAN}

Berdasarkan tabel 1 menunjukkan bahwa terdapat hubungan antara kebiasaan makan di 
luar rumah $(\mathrm{p}=0,001 ; \mathrm{OR}=5,39 ; 95 \% \mathrm{CI}=1,97$ 14,74), kebiasaan mencuci tangan sebelum makan $(\mathrm{p}=0,02 ; \mathrm{OR}=3,46 ; 95 \% \mathrm{CI}=1,30-9,19)$, kebiasaan mencuci tangan setelah $\mathrm{BAB}(\mathrm{p}=0,04$; $\mathrm{OR}=2,99 ; \quad 95 \% \mathrm{CI}=1,15-7,73), \quad$ kebiasaan mencuci bahan makanan mentah $(\mathrm{p}=0,007$; $\mathrm{OR}=4,97 ; \quad 95 \% \mathrm{CI}=1,63-15,15)$, dan jamban sehat $(p=0,04 ; \quad O R=2,87 ; \quad 95 \% C I=1,13-7,25)$ dengan kejadian demam tifoid di Puskesmas Pagiyanten Kabupaten Tegal. Sedangkan tidak terdapat hubungan antara umur, jenis kelamin, keadaan sosial ekonomi, dan riwayat keluarga dengan kejadian demam tifoid di Puskesmas Pagiyanten Kabupaten Tegal.

Berdasarkan tabel 1, diketahui bahwa hasil analisis bivariat antara umur dengan kejadian demam tifoid menunjukkan tidak terdapat hubungan yang bermakna antara umur responden dengan kejadian demam tifoid di Puskesmas Pagiyanten Kabupaten Tegal $(\mathrm{p}=1,00)$.
Berdasarkan Laporan RISKESDAS tahun 2007 menunjukkan bahwa prevalensi demam tifoid di Indonesa terjadi pada kelompok usia 5-14 tahun, dimana pada usia tersebut anak cenderung kurang memperhatikan kebersihan diri serta kebiasaan jajan sembarangan yang dapat menyebabkan penularan demam tifoid (Depkes RI, 2008). Hasil penelitian ini sejalan dengan penelitian yang dilakukan oleh Artanti (2013) di wilayah kerja Puskesmas Kedungmundu Kota Semarang yang menyebutkan bahwa tidak ada hubungan antara umur responden dengan kejadian demam tifoid. Pada penelitian tersebut diketahui proporsi umur berisiko pada kelompok kasus seimbang dengan kelompok kontrol. Hal tersebut sama dengan hasil penelitian di lapangan yang menunjukkan proporsi umur berisiko pada kelompok kasus sebesar 86\% seimbang dengan kelompok kontrol sebesar $86 \%$. Hasil penelitian di lapangan didapatkan

Tabel 1 Distribusi Analisis Bivariat Faktor yang Berhubungan dengan Kejadian Demam Tifoid

\begin{tabular}{|c|c|c|c|c|c|c|c|c|}
\hline \multirow{3}{*}{ No } & \multirow{3}{*}{ Variabel } & \multirow{3}{*}{ Kategori } & \multicolumn{4}{|c|}{ Frekuensi (n) } & \multirow{3}{*}{ OR $(95 \% \mathrm{CI})$} & \multirow{3}{*}{$p$-value } \\
\hline & & & \multicolumn{2}{|c|}{ Kasus } & \multicolumn{2}{|c|}{ Kontrol } & & \\
\hline & & & $\mathrm{N}$ & $\%$ & $\mathrm{~N}$ & $\%$ & & \\
\hline \multirow[b]{2}{*}{1} & \multirow[b]{2}{*}{ Umur } & Berisiko ( $\leq 30$ tahun) & 37 & 86 & 37 & 86 & & \multirow[b]{2}{*}{1,00} \\
\hline & & $\begin{array}{l}\text { Tidak Berisiko (> } 30 \\
\text { tahun) }\end{array}$ & 6 & 14 & 6 & 14 & & \\
\hline \multirow{2}{*}{2} & \multirow{2}{*}{ Jenis kelamin } & Laki-laki & 18 & 41,9 & 18 & 41,9 & & \multirow{2}{*}{1,00} \\
\hline & & Perempuan & 25 & 58,1 & 25 & 58,1 & & \\
\hline \multirow{2}{*}{3} & Keadaan Sosial & Rendah & 9 & 20,9 & 6 & 14 & & \multirow{2}{*}{0,57} \\
\hline & Ekonomi & Tinggi & 34 & 79,1 & 37 & 86 & & \\
\hline \multirow{3}{*}{4} & \multirow{3}{*}{$\begin{array}{l}\text { Kebiasaan } \\
\text { Makan di Luar } \\
\text { Rumah }\end{array}$} & $\begin{array}{l}\text { Sering ( } \geq 3 \text { kali } \\
\text { semingoul) }\end{array}$ & 36 & 83,7 & 21 & 48,8 & 5,39 & \multirow{3}{*}{0,001} \\
\hline & & $\begin{array}{l}\text { Seminggu) } \\
\text { Jarang }(<3 \text { kali }\end{array}$ & & & & & & \\
\hline & & $\begin{array}{l}\text { Jarang }(<3 \text { Kall } \\
\text { seminggu })\end{array}$ & 7 & 16,3 & 22 & 51,2 & $(1,97-14,74)$ & \\
\hline \multirow[b]{2}{*}{5} & \multirow{2}{*}{$\begin{array}{l}\text { Kebiasaan } \\
\text { Mencuci Tangan } \\
\text { Sebelum Makan }\end{array}$} & Kurang Baik & 35 & 81,4 & 24 & 55,8 & 3,46 & \multirow[b]{2}{*}{0,02} \\
\hline & & Baik & 8 & 18,6 & 19 & 44,2 & $(1,30-9,19)$ & \\
\hline \multirow[b]{2}{*}{6} & \multirow{2}{*}{$\begin{array}{l}\text { Kebiasaan } \\
\text { Mencuci Tangan } \\
\text { Setelah BAB }\end{array}$} & Kurang Baik & 34 & 79,1 & 24 & 55,8 & 2,99 & \multirow[b]{2}{*}{0,04} \\
\hline & & Baik & 9 & 20,9 & 19 & 44,2 & $(1,15-7,73)$ & \\
\hline \multirow[b]{2}{*}{7} & \multirow{2}{*}{$\begin{array}{l}\text { Kebiasaan } \\
\text { Mencuci Bahan } \\
\text { Makanan } \\
\text { Mentah }\end{array}$} & Kurang Baik & 17 & 39,5 & 5 & 11,6 & 4,97 & \multirow[b]{2}{*}{0,007} \\
\hline & & Baik & 26 & 60,5 & 38 & 88,4 & $(1,63-15,15)$ & \\
\hline \multirow{2}{*}{8} & \multirow{2}{*}{ Jamban Sehat } & $\begin{array}{l}\text { Tidak Memenuhi } \\
\text { Syarat }\end{array}$ & 33 & 76,7 & 23 & 53,5 & 2,87 & \multirow{2}{*}{0,04} \\
\hline & & Memenuhi Syarat & 10 & 23,3 & 20 & 46,5 & $(1,13-7,25)$ & \\
\hline \multirow{2}{*}{9} & Riwayat & Ada & 15 & 34,9 & 7 & 16,3 & & \multirow{2}{*}{0,08} \\
\hline & Keluarga & Tidak Ada & 28 & 65,1 & 36 & 83,7 & & \\
\hline
\end{tabular}


bahwa sebagian besar responden kasus mempunyai umur berisiko ( $\leq 30$ tahun) sebanyak 37 orang atau $86 \%$ dan responden kasus yang mempunyai umur tidak berisiko ( $>30$ tahun) sebanyak 6 orang atau $14 \%$. Hal ini sesuai dengan penelitian yang dilakukan oleh Bukhari (2016) yang juga menunjukkan bahwa distribusi kasus demam tifoid menurut umur dengan risiko tinggi di daerah Taxila, Pakistan yaitu terletak pada rentang kelompok usia 10-15 tahun dan 25-35 tahun.

Berdasarkan tabel 1, diketahui bahwa hasil analisis bivariat antara jenis kelamin dengan kejadian demam tifoid menunjukkan tidak terdapat hubungan yang bermakna antara jenis kelamin responden dengan kejadian demam tifoid di Puskesmas Pagiyanten Kabupaten Tegal $(p=1,00)$. Jenis kelamin mempengaruhi status kesehatan karena ada penyakit tertentu yang lebih banyak terjadi atau hanya ditemukan pada jenis kelamin perempuan atau hanya pada laki-laki, seperti pada wanita terjadi kanker serviks dan pada laki-laki terjadi kanker prostat (Lidya, 2010 dalam Wijaya, 2015). Hasil penelitian ini tidak sejalan dengan penelitian yang dilakukan oleh Wijaya (2015) di Puskesmas Bugangan Kota Semarang yang menunjukkan ada hubungan antara jenis kelamin dengan kejadian demam tifoid ( $\mathrm{p}=0,037)$.

Perbedaan hasil penelitian terlihat dari karakteristik responden pada kelompok kasus dan kontrol. Hasil penelitian tersebut penderita demam tifoid lebih banyak terjadi pada jenis kelamin laki-laki yaitu sebesar $69,2 \%$ dibandingkan dengan jenis kelamin perempuan yaitu sebesar $30,8 \%$. Sedangkan hasil penelitian di lapangan diketahui bahwa proporsi responden kasus sama dengan responden kontrol. Selain itu sebagian besar kasus demam tifoid terjadi pada jenis kelamin perempuan yaitu sebanyak 25 orang $(58,1 \%)$ dan responden laki-laki hanya 18 orang $(41,9 \%)$. Hal ini berbeda dengan kebanyakan kasus demam tifoid yang lebih sering terjadi pada jenis kelamin lakilaki dan dikaitkan bahwa laki-laki lebih banyak melakukan aktivitas di luar rumah sehingga memungkinkan laki-laki berisiko lebih besar terinfeksi Salmonella typhi dibandingkan perempuan (Artanti, 2013).

Berdasarkan tabel 1, diketahui bahwa hasil analisis bivariat antara keadaan sosial ekonomi dengan kejadian demam tifoid menunjukkan bahwa tidak terdapat hubungan yang bermakna antara keadaan sosial ekonomi dengan kejadian demam tifoid di Puskesmas Pagiyanten Kabupaten Tegal $(p=0,57)$. Menurut Rejeki (2015), status sosial ekonomi mempengaruhi kemampuan seseorang dalam memenuhi sarana dan prasarana yang digunakan untuk mempertahankan kebersihan diri yang sangat mempengaruhi status kesehatannya. Umumnya masyarakat dengan status sosial ekonomi rendah tidak mengutamakan perawatan dan kebersihan dirinya sendiri sehingga dapat menurunkan status kesehatannya.

Hasil penelitian ini tidak sejalan dengan penelitian yang dilakukan oleh Artanti (2013) di wilayah kerja Puskesmas Kedungmundu Kota Semarang yang menyebutkan bahwa ada hubungan antara tingkat sosial ekonomi dengan kejadian demam tifoid dengan nilai $\mathrm{p}=0,016<$ $\alpha(0,05)$ dan nilai $\mathrm{OR}=8,800$. Pada penelitian tersebut proporsi responden dengan tingkat ekonomi rendah pada kelompok kasus sebesar 61,5\% lebih besar dari kelompok kontrol sebesar $15,4 \%$. Sedangkan pada penelitian ini proporsi responden dengan tingkat ekonomi rendah pada kelompok kasus sebesar 20,9\%, hampir seimbang dengan kelompok kontrol sebesar $14 \%$. Hasil penelitian di lapangan menunjukkan bahwa sebagian besar responden kasus berada pada tingkat sosial ekonomi yang tinggi $(79,1 \%)$ sedangkan responden dengan tingkat ekonomi yang rendah lebih sedikit yaitu sebesar 20,9\%. $\mathrm{Hal}$ ini menunjukkan adanya perbedaan dari kebanyakan kasus yang menunjukkan bahwa demam tifoid lebih banyak terjadi pada kalangan status ekonomi rendah.

Berdasarkan tabel 1, diketahui bahwa hasil analisis bivariat antara kebiasaan makan di luar rumah dengan kejadian demam tifoid menunjukkan bahwa terdapat hubungan yang bermakna antara kebiasaan makan di luar rumah dengan kejadian demam tifoid di 
Puskesmas Pagiyanten Kabupaten Tegal $(\mathrm{p}=0,001 ; \quad \mathrm{OR}=5,39 ; \quad 95 \% \mathrm{CI}=1,97-14,74)$. Menurut Welong (2017) menyatakan bahwa penularan demam tifoid dapat terjadi dimana saja dan kapan saja, biasanya terjadi melalui konsumsi makanan di luar rumah atau di tempat-tempat umum, apabila makanan atau minuman yang dikonsumsi kurang terjaga kebersihannya. Selain itu menurut penelitian yang di lakukan Erfianto (2017) tentang hygiene personal pada penjual nasi kucing, didapatkan hasil bahwa tidak ada penjual yang mencuci tangan sebelum menyajikan makanan dan hanya $10 \%$ yang mencuci alat makan dengan menggunakan sabun dan air yang mengalir. Hal ini dapat menjadi media penularan penyakit demam tifoid karena makanan yang di sajikan tidak dalam kondisi bersih dan sudah tercemar. Hasil penelitian ini sejalan dengan penelitian yang dilakukan Seran (2015) di wilayah kerja Puskesmas Tumaratas Kecamatan Lawongan Barat yang menunjukkan bahwa adanya hubungan antara kebiasaan makan diluar rumah dengan kejadi demam tifoid dengan nilai $\mathrm{p}$ $(0,031)<\alpha(0,05)$ dan $\mathrm{OR}=5,00$. Hal ini diperkuat dengan hasil penelitian Alba (2016) yang menyebutkan bahwa kebiasaan makan di warung atau restoran merupakan faktor risiko yang penting dalam penularan demam tifoid di kepulauan Indonesia dengan nilai OR sebesar 6,9. Hasil penelitian di lapangan menunjukkan bahwa sebagian besar $(66,3 \%)$ rsponden mempunyai kebiasaan makan di luar rumah yang sering ( $\geq 3$ kali seminggu). Hal ini terjadi karena sebagian besar responden $(51,2 \%)$ dalam penelitian ini merupakan seorang pelajar, dimana mereka lebih sering mengkonsumsi makanan atau jajanan yang dijual di lingkungan sekolah yang belum terjamin kebersihannya. Berdasarkan wawancara dengan responden, didapat sebagian besar responden mempunyai kebiasaan makan di luar rumah seperti di sekolah, warung makan, dan pedagang keliling. Jenis makanan yang sering dikonsumsi beraneka ragam seperti olos, siomay, gorengan, sosis bakar, cilok, dan juga es kemasan. Responden lebih menyukai makanan tersebut karena harga yang terjangkau, murah dan rasanya enak serta disenangi oleh kalangan anak-anak sehingga mereka sering mengabaikan kebersihan dari makanan tersebut. Jajanan tersebut biasa dijual oleh pedagang di pinggir jalan dengan keadaan terbuka sehingga dengan mudah debu dan lalat dapat hinggap. Kuman Salmonella typhi yang dibawa oleh lalat dapat mencemari makanan yang dihinggapi, sehingga orang yang mengkonsumsi makanan tersebut dapat berisiko menderita demam tifoid. Menurut Maarisit (2014) menyatakan bahwa kualitas kebersihan makanan yang kurang diperhatikan oleh penjual makanan jajan dapat menyebabkan makanan tersebut menjadi menjadi suatu bibit penyakit dan penyakit yang timbul salah satunya adalah demam tifoid.

Berdasarkan tabel 1, diketahui bahwa hasil analisis bivariat antara kebiasaan mencuci tangan sebelum makan dengan kejadian demam tifoid menunjukkan bahwa terdapat hubungan yang bermakna antara kebiasaan mencuci tangan sebelum makan dengan kejadian demam tifoid di Puskesmas Pagiyanten Kabupaten Tegal $(\mathrm{p}=0,02 ; \mathrm{OR}=3,46 ; 95 \% \mathrm{CI}=1,30-9,19)$. Penularan bakteri Salmonella typhi salah satunya melalui jari tangan atau kuku. Jika seseorang kurang memperhatikan kebersihan dirinya seperti mencuci tangan sebelum makan maka bakteri tersebut dapat masuk ke dalam tubuh orang sehat melalui mulut kemudian menjadikan orang tersebut menjadi sakit (Maghfiroh, 2016). Hasil penelitian ini sejalan dengan penelitian Hudayani (2013) di RSUD Kebumen yang menyatakan bahwa kebiasaan mencuci tangan sebelum makan merupakan faktor risiko terjadinya demam tifoid $(\mathrm{OR}=2,835)$. Hal ini diperkuat dengan hasil penelitian Paputungan (2016) di wilayah kerja Puskesmas Upai Kota Kotamobagu yang menunjukkan bahwa ada hubungan antara kebiasaan mencuci tangan menggunakan sabun sebelum makan dengan kejadian demam tifoid dengan nilai $p(0,047)<\alpha(0,05)$. Hasil penelitian di lapangan menunjukkan bahwa sebagian besar responden kasus mempunyai kebiasaan cuci tangan sebelum makan yang kurang baik yaitu sebanyak 35 orang $(81,4)$ dan lainnya $(18,6 \%)$ mempunyai kebiasaan mencuci 
tangan yang baik. Hal ini terjadi karena masih banyak responden yang kurang menyadari pentingnya mencuci tangan sebelum makan. Menurut beberapa responden, mereka lebih sering makan dengan menggunakan alat makan jadi tidak perlu mencuci tangan terlebih dahulu. Selain mereka juga tidak mengetahui cara atau langkah mencuci tangan yang baik dan benar yaitu dengan menggunakan sabun dan air mengalir, serta menggosok tangan, sela-sela jari dan kuku.

Berdasarkan tabel 1, diketahui bahwa hasil analisis bivariat antara kebiasaan mencuci tangan setelah buang air besar dengan kejadian demam tifoid menunjukkan bahwa terdapat hubungan yang bermakna antara kebiasaan mencuci tangan setelah buang air besar dengan kejadian demam tifoid di Puskesmas Pagiyanten Kabupaten Tegal $\quad(p=0,04 ; \quad O R=2,99$; $95 \% \mathrm{CI}=1,15-7,73)$. Tangan yang kotor atau terkontaminasi dapat memindahkan bakteri atau virus patogen dari tubuh, feses atau sumber lain ke makanan. Oleh karenanya kebersihan tangan dengan mencuci tangan perlu mendapat prioritas tinggi, walaupun hal tersebut sering disepelekan pencucian dengan sabun sebagai pembersih, penggosokkan dan pembilasan dengan air mengalir akan menghanyutkan partikel kotoran yang banyak mengandung mikroorganisme (Maghfiroh, 2016). Hasil penelitian ini sejalan dengan penelitian Paputungan (2016) di wilayah kerja Puskesmas Upai Kota Kotamobagu yang menyebutkan bahwa ada hubungan antara kebiasaan mencuci tangan dengan sabun setelah buang air besar dengan kejadian demam tifoid dengan nilai $\mathrm{p}$ $(0,041)<\alpha(0,05)$. Pada penelitian tersebut didapatkan bahwa kejadian demam tifoid lebih banyak terjadi pada responden yang mempunyai kebiasaan mencuci tangan setalah $\mathrm{BAB}$ yang kurang baik $(57,3 \%)$. Berdasarkan hal tersebut penelitian ini memiliki kemiripan karakteristik responden yaitu sebagian besar kejadian demam tifoid juga dialami oleh responden yang memiliki kebiasaan mencuci tangan setelah BAB yang kurang baik $(79,1 \%)$. Hasil penelitian di lapangan didapatkan bahwa responden yang mempunyai kebiasaan mencuci tangan setelah buang air besar kurang baik sebanyak 58 orang atau sebesar $67,4 \%$ lebih banyak jika dibandingkan dengan responden yang mempunyai kebiasaan mencuci tangan setelah buang air besar yang baik yaitu hanya 28 orang $(32,6 \%)$. Berdasarkan wawancara yang dilakukan dengan responden didapatkan semua responden sudah mencuci tangan mereka menggunakan sabun setelah buang air besar. Namun masih banyak di antara mereka masih belum mengetahui cara atau langkah mencuci tangan yang baik dan benar. Hal ini dikarenakan kurangnya pengetahuan responden dalam menjaga kebersihan diri khususnya kebersihan tangan, karena tangan merupakan salah satu media penularan penyakit demam tifoid.

Berdasarkan tabel 1, diketahui bahwa hasil analisis bivariat antara kebiasaan mencuci bahan makanan mentah dengan kejadian demam tifoid menunjukkan bahwa terdapat hubungan yang bermakna antara kebiasaan mencuci bahan makanan mentah dengan kejadian demam tifoid di Puskesmas Pagiyanten Kabupaten Tegal $(\mathrm{p}=0,007 ; \mathrm{OR}=4,97 ; 95 \%$ $\mathrm{CI}=1,63-15,15)$. Bahan makanan seperti daging, ikan, telur, sayur, dan buah sebelum diolah harus dicuci terlebih dahulu. Terutama pada makanan yang akan dikonsumsi langsung atau dalam keadaan mentah. Bahan-bahan hewani biasanya masih mengandung kuman pathogen sedangkan pada buah dan sayur seringkali mengandung pestisida atau pupuk. Oleh karena itu perlu dilakukan pencucian dengan air bersih dan mengalir. Penelitian ini sejalan dengan penelitian yang dilakukan Seran (2015) di wilayah kerja Puskesmas Tumaratas yang menyebutkan bahwa ada hubungan antara kebiasaan mencuci bahan makanan mentah yang akan langsung dikonsumsi dengan kejadian demam tifoid dengan nilai $\mathrm{p}(0,029)<$ $\alpha(0,05)$ dan nilai OR sebesar 5,2 , sehingga dapat dikatakan bahwa responden yang mempunyai kebiasaan mencuci bahan makanan mentah yang kurang baik lebih berisiko 5,2 kali menderita demam tifoid daripada responden yang mempunyai kebiasaan yang baik dalam mencuci bahan makanan mentah yang langsung 
konsumsi. Penelitian yang dilakukan di Uzbekistan tahun 2007 juga menyebutkan bahwa rutin mencuci sayuran merupakan faktor protektif terhadap penyakit demam tifoid (Srikantiah, 2007). Hasil penelitian di lapangan diketahui bahwa responden yang menderita demam tifoid sebagian besar mempunyai kebiasaan mencuci bahan makanan mentah yang baik yaitu sebesar $60,5 \%$ jika dibandingkan dengan responden yang mempunyai kebiasaan mencuci bahan makanan mentah yang kurang baik (39,5\%). Berdasarkan wawancara yang dilakukan dengan responden didapatkan masih ada sebagian yang tidak mencuci bahan makanan mentah yang akan langsung di makan. Dalam hal ini responden sering mengkonsumsi buah seperti apel, anggur, jambu air, dan pir. Selain itu juga mereka mengkonsumsi sayuran seperti tomat, mentimu, kubis, dan daun kemangi. Responden setelah membeli sayur dan buah tersebut biasanya lansung disimpan di lemari pendingin tanpa dicuci terlebih dahulu. Ada juga responden yang lansung mengkonsumsi makanan tersebut. Menurut mereka sayur dan buah tersebut terlihat bersih dan masih segar sehingga tidak perlu dicuci terlebih dahulu. Namun mereka tidak mengetahui bahwa buah dan sayuran yang dipupuk menggunakan kotoran manusia dapat terkontaminasi bakteri Salmonella typhi, sehingga mengkonsumsi buah dan sayur tanpa dicuci terlebih dahulu dapat meningkatkan risiko penyakit demam tifoid.

Berdasarkan tabel 1, diketahui bahwa hasil analisis bivariat antara riwayat keluarga dengan kejadian demam tifoid menunjukkan bahwa tidak terdapat hubungan yang bermakna antara riwayat keluarga dengan kejadian demam tifoid di Puskesmas Pagiyanten Kabupaten Tegal $(p=0,08)$. Riwayat penyakit demam tifoid dalam satu keluarga sangat berpengaruh karena penularan yang dialami akan melalui jalan yang sama dan risiko tertular akan semakin cepat. Seseorang mampu menjadi pembawa penyakit (asymptomatic carrier) demam tifoid, tanpa menunjukkan tanda gejala tetapi mampu menularkan ke orang lain. Status carrier dapat terjadi setelah mendapat serangan akut.
Carrier kronis harus diawasi dengan ketat dan dilarang melakukan pekerjaan yang dapat menularkan penyakit kepada orang lain. Feses penderita merupakan sumber utama bagi penularan demam tifoid (Nuruzzaman, 2016). Hasil penelitian ini tidak sejalan dengan penelitian Rakhman (2009) pada pasien rawat inap di RSUD dr. H Soemarno Sostroatmodjo Kabupaten Bulungan Kalimantan Timur yang menunjukkan bahwa ada hubungan antara riwayat demam tifoid dalam keluarga dengan kejadian demam tifoid pada orang dewasa dengan nilai 95\% CI $=1,22-4,05$ serta nilai $\mathrm{OR}=2,24$. Hal ini berarti responden dengan riwayat demam tifoid dalam keluarga lebih berisiko 2,24 kali menderita demam tiofid daripada responden yang tidak memiliki riwayat demam tifoid dalam keluarga. Penelitian Javaid (2008) juga menyebutkan bahwa salah satu faktor risiko demam tifoid pada anak adalah karena kurangnya pengetahuan tentang kontak langsung dengan penderita demam tifoid. Hasil penelitian di lapangan menunjukkan bahwa responden kasus yang memiliki riwayat demam tifoid dalam keluarga sebanyak 15 orang (34,9\%) lebih sedikit dibandingkan responden kasus yang tidak memiliki riwayat demam tifoid dalam keluarga yaitu sebanyak 28 orang (65,1\%).

Berdasarkan tabel 1, diketahui bahwa hasil analisis bivariat antara jamban sehat dengan kejadian demam tifoid menunjukkan bahwa terdapat hubungan yang bermakna antara jamban sehat dengan kejadian demam tifoid di Puskesmas Pagiyanten Kabupaten Tegal $(p=0,04 ; \quad O R=2,87 ; 95 \% C I=1,13-7,25)$. Menurut Artanti (2013) menyatakan bahwa tinja dapat menjadi perantara penyakit menular yang biasanya dapat menyerang masyarakat. Proses pemindahan kuman penyakit dari tinja sebagai pusat infeksi sampai inang baru dapat melalui berbagai media perantara, antara lain air, tangan, serangga, tanah, makanan serta sayuran. Pembuangan tinja dan limbah cair yang dilaksanakan secara saniter akan memutuskan rantai penularan penyakit. Hasil penelitian ini tidak sejalan dengan penelitian Rakhman (2009) yang menyatakan bahwa tidak 
ada hubungan antara kepemilikan jamban yang memenuhi syarat dengan kejadian demam tifoid pada orang dewasa dengan nilai $\mathrm{p}=0,805$. Perbedaan hasil penelitian tersebut terdapat pada karakterisitik responden dilihat pada jumlah proporsi responden yang memiliki jamban yang memnuhi syarat kesehatan sebesar $58,8 \%$, lebih besar dibandingkan dengan responden yang memiliki jamban yang tidak memenuhi syarat kesehatan yaitu sebesar $41,2 \%$. Hasil di lapangan menunjukkan bahwa sebesar $65,1 \%$ dari responden memiliki sarana pembungan tinja (jamban) yang tidak memenuhi syarat kesehatan lebih besar dibandingkan dengan responden yang memiliki sarana pembungan tinja (jamban) yang memenuhi syarat kesehatan yaitu sebesar $34,9 \%$. Terdapat sebanyak 33 responden yang menderita demam tifoid memiliki jamban yang tidak memenuhi syarat kesehatan. Persyaratan sarana pembuangan tinja yang baik antara lain 1) jarak sumber air dengan lubang penampung minimal 11 meter; 2) tidak berbau; 3) bebas dari serangga maupun tikus; 4) mudah dibersihkan; 5) dilengkapi dinding dan atap pelindung; 6) pencahayaan dan ventilasi yang cukup; 7) lantai kedap air; dan 8) tersedia air, sabun dan alat pembersih. Berdasarkan hasil observasi ditemukan masih banyak jamban yang tidak memenuhi syarat kesehatan seperti letak tangki septik dan sumber air tidak lebih dari 11 meter. Lantai kamar mandi banyak yang rusak, kurangnya ventilasi sehingga pencahayaan kurang, serta masih ditemukan kecoa di beberapa kamar mandi responden. Selain itu dari wawancara dengan responden, mereka mengatakan jarang membersihkan kamar mandi, jika dibersihkanpun hanya menyikat tanpa menggunakan sabun. Kondisi jamban yang tidak memenuhi syarat tersebut dan disertai dengan keberadaan serangga (lalat dan kecoa) di sekitar jamban dapat berpotensi sebagai media penularan demam tifoid.

\section{PENUTUP}

Simpulan penelitian ini menunjukkan bahwa terdapat hubungan antara kebiasaan makan di luar rumah, kebiasaan mencuci tangan sebelum makan, kebiasaan mencuci tangan setelah buang air besar, kebiasaan mencuci bahan makanan mentah, dan jamban sehat dengan kejadian demam tifoid di Puskesmas Pagiyanten Kabupaten Tegal. Sedangkan tidak terdapat hubungan antara umur responden, jenis kelamin, keadaan sosial ekonomi, dan riwayat keluarga dengan kejadian demam tifoid di Puskesmas Pagiyanten Kabupaten Tegal.

Saran yang direkomendasikan untuk penelitian selanjutnya adalah perlu adanya penelitian lebih lanjut dengan memperluas sampel penelitian, jenis desain penelitian dan variabel yang berbeda untuk lebih mengetahui faktor lain yang berhubungan dengan kejadian demam tifoid.

\section{DAFTAR PUSTAKA}

Alba, S., Bakker, M. I., Hatta, M., Scheelbeek, P. F. D., Dwiyanti, R., Usman, R., and Smits, H. L. 2016. Risk Factors of Typhoid Infection in the Indonesian Archipelago. PLOS ONE, 11(6): $1-14$

Artanti. 2013. Hubungan Antara Sanitasi Lingkungan, Higiene Perorangan, dan Karakteristik Individu dengan Kejadian Demam Tifoid di Wilayah Kerja Puskesmas Kedungmundu Kota Semarang Tahun 2012. Skripsi. Semarang: Universitas Negeri Semarang

Batubuaya, D., Ratag, B, T., Wariki, W. 2017. Hubungan Higiene Perorangan dan Aspek Sosial Ekonomi Dengan Kejadian Demam Tifoid di Rumah Sakit Tk.III R.W. Mongisidi Manado. Jurnal Media Kesehatan, 9(3): 1-8

Bukhari, N., Saleem, A., Jabbar, A., Noor, Khan, S., Ahmad, B., and Ahmad, K. A. 2016. Frequency of Typhoid Fever and Its Association with Seasonal Variations in Taxila, Pakistan. Asian Pasific Journal of Tropical Disease, 6(8): 608-610

Depkes RI. 2008. Laporan Riset Kesehatan Dasar Tahun 2007. Jakarta: Departemen Kesehatan Republik Indonesia

Erfianto, R., dan Koesyanto, H. 2017. Hygiene Personal pada Penjual Nasi Kucing. HIGEIA, 1(1): 48-51

Hudayani, R., Kusnanto, H., Humardewayanti, R., and Agung, W. 2013. Risk Factors Analysis of 
Typhoid Fever Occurence of Inpatient in Kebumen Public Hospital in 2013. Tropical Medicine Journal, 03(02): 103-109

Javaid, F., Rizwan, S., Ahmed, Z. 2008. Risk Factors for Typhoid Fever in Children Squatter Settlements of Karachi: A Nested CaseControl Study. Journal of Infection and Public Health, 1: 113-120

Kusuma, B. F., Saleh, I., Selviana. 2015. Faktor Risiko Kejadian yang Berhubungan dengan Kejadian Demam Tifoid pada Anak di Wilayah Kerja Puskesmas Sui Kakap dan Puskesmas Sui Durian. JUMANTIK (Jurnal Mahasiswa dan Penelitian Ilmiah), 2(1): 41-53

Maarisit, C. L., Sarimin, S., Babakal, A. 2014. Hubungan Pengetahuan Orang Tua tentang Demam Tifoid dengan Kebiasaan Jajan pada Anak di Wilayah Kerja RSUD Mala Kecamatan Melonguane Kabupaten Kepulauan Talaud. Jurnal Keperawatan, 2(2)

Maghfiroh, A. E., Siwiendrayanti, A. 2016. Hubungan Cuci Tangan, Tempat Sampah, Kepemilikan SPAL, Sanitasi Makanan dengan Demam Tifoid. Jurnal Pena Medika, 6(1): $34-45$

Malau, V. M., Budiyono, Yusniar. 2015. Hubungan Higiene Perorangan dan Sanitasi Makanan Rumah Tangga dengan Kejadian Demam Tifoid pada Anak Umur 5-14 Tahun di Wilayah Kerja Puskesmas Bandarharjo Kota Semarang. Jurnal Kesehatan Masyarakat, 3(1): 589-598

Nadyah. 2014. Hubungan Faktor-faktor yang Mempengaruhi Insidens Penyakit Demam Tifoid di Kelurahan Samata Kecamatan Somba Opu Kabupaten Gowa 2013. Jurnal Kesehatan, 7(1): 305-321

Nuruzzaman, H., Syahrul, F. 2016. Analisis Risiko Kejadian Demam Tifoid Berdasarkan Kebersihan Diri dan Kebiasaan Jajan di Rumah. Jurnal Berkala Epidemiologi, 4(1): 7486

Paputungan, W., Rombot, D., dan Akili, R, H. 2016. Hubungan Antara Perilaku Hidup Bersih dan Sehat dengan Kejadian Demam Tifoid di Wilayah Kerja Puskesmas Upai Kota Kotamobagu Tahun 2015. Jurnal Ilmiah Farmasi, 5(2)

Parry, C. M., Thompson, C., Vinh, H., Chinh, N. T., Phuong, L. T., Ho, V. A., Hien, T. T., Wain, J., Farrar, J. J., and Baker, S. 2014. Risk Factors for The Development of Severe
Typhoid Fever in Vietnam. BMC Infection Diseases, 14(73): 1-9

Pramitasari, O, P. 2013. Faktor Risiko Kejadian Penyakit Demam Tifoid pada Penderita Yang Dirawat Di Rumah Sakit Umum Daerah Ungaran. Jurnal Kesehatan Masyarakat, 2(1): 110

Rakhman, A., Humardewayanti, R., dan Pramono, D. 2009. Faktor-faktor Risiko yang Berhubungan terhadap Kejadian Demam Tifoid pada Orang Dewasa. Jurnal Berita Kedokteran Masyarakat, 25(4)

Ramaningrum, G., Anggraheny, H. D., dan Putri, T. P. 2016. Faktor-faktor yang Mempengaruhi Kejadian Demam Tifoid pada Anak di RSUD Tugurejo Semarang. Jurnal Kedokteran Muhammadiyah, 5(2): 1-8

Rampengan, T. H. 2007. Penyakit Infeksi Tropik pada Anak. Jakarta: EGC

Rejeki, S. 2015. Sanitasi hygiene dan K3 (Kesehatan \& Keselamatan Kerja). Bandung: Rekayasa Sains

Ruztam, M, Z, A. 2012. Hubungan Karakteristik Penderita Dengan Kejadian Demam Tifoid pada Pasien Rawat Inap di RSUD Salewangan Maros. Jurnal Ilmiah Kesehatan STRADA, 1(2): 58-63

Seran, E. R., Palandeng, H., dan Kallo, V, D. 2015. Hubungan Personal Hygiene dengan Kejadian Demam Tifoid di Wilayah Kerja Puskesmas Tumaratas. E-Journal Keperawatan (e-Kp), 3(2): $1-8$

Srikantiah, P., Vafokulov, S., Luby, S, P., Ishmail, T., Earhart, K., Khodjaev, N., Jennings, G., Crump, J, A., and Mahoney, F, J. 2007. Epidemiology and Risk Factors for Endemic Typhoid Fever in Uzbekistan. Tropical Medicine and International Health, 12(7): 838847

Sur, D., Ali, M., Seidlein, L., Von, Manna, B., Deen, J. L., Acosta, C. J., Bhattacharya, S. K. 2007. Comparisons of Predictors for Typhoid and Paratyphoid Fever in Kolkata, India. BMC Public Health, 7(289): 1-10

Tjipto, B. W., Kristiana, L., Ristrini. 2009. Kajian Faktor Pengaruh terhadap Penyakit Demam Tifoid pada Balita Indonesia. Buletin Penelitian Sistem Kesehatan, 12(4): 313-340

Welong, S. S., Ratag, B. T., Bernadus, J. 2017. Analisis Faktor Risiko Kejadian Demam Tifoid pada Pasien Rawat Inap di Rumah Sakit Advent Manado Tahun 2016. Public Health Journal, 6(3): 1-11. 
Farissa U., dan Oktia W. K. H./Kejadian Demam Tifoid / HIGEIA 2 (2) (2018)

Wijaya, K., dan Sugiyanto, Z. 2015. Faktor Risiko yang Berhubungan dengan Kejadian Demam Tifoid di Puskesmas Bugangan Kota Semarang
Tahun 2015. Artikel Ilmiah. Semarang: Universitas Dian Nuswantoro 